\title{
ANALISIS KEBIJAKAN PEMBELAJARAN SECARA LURING DI SMK VETERAN 1 SUKOHARJO
}

\author{
Narani Agesti \\ Universitas Veteran Bangun Nusantara Sukoharjo \\ naraniagesti103@gmail.com \\ Muhammad Nur Isdaryono \\ SMK Veteran 1 Sukoharjo \\ muhammadnurisdaryono4@gmail.com \\ Fauzi Rachman \\ Universitas Veteran Bangun Nusantara Sukoharjo \\ fauzirachman.veteranbantara@gmail.com
}

\begin{abstract}
ABSTRAK
PPL merupakan salah satu mata kuliah di Universitas Veteran Bangun Nusantara Sukoharjo dengan menerjunkan mahasiswa ke lapangan untuk praktik secara langsung di sekolah. Penelitian ini mengguanakan metode kualitatif deskriptif. Pada bulan Agustus 2020, pemerintah melalui Kementerian Pendidikan dan Kebudayaan mengeluarkan kebijakan baru diantara kurikulum darurat dan perluasan pembelajaran tatap muka untuk zona kuning dan hijau. Hasil penelitian ini menunjukkan bahwa pembelajaran secara luring sangat efektif dan efisien jika dilihat dari dampak negatif yang diberikan dari pembelajaran secara daring seperti diantaranya ancaman putus sekolah, penurunan capaian belajar dan kekerasan pada anak dan risiko eksternal dapat merusak sumber daya manusia yang ada di Indonesia.
\end{abstract}

Kata Kunci: PPL, Luring, Daring, Covid- 19, Kebijakan.

\section{PENDAHULUAN}

Ditegaskan dalam undang-undang No. 20 tahun 2003 tentang sistem pendidikan nasional yang menyebutkan bahwa pendidikan nasional bertujuan untuk mencerdaskan kehidupan bangsa dan mengembangkan manusia seutuhnya yaitu manusia yang beriman bertakwa kepada Tuhan Yang Maha Esa, berbudi luhur, kepribadian yang mantab dan mandiri serta bertanggung jawab terhadap masyarakat dan bangsa. Sesuai dengan tujuan tersebut mahasiswa Universitas Veteran Bangun Nusantara Sukoharjo khususnya program kependidikan diharapkan mampu menguasai materi kependidikan baik secara teori maupun praktik. Tenaga pendidik atau guru mempunyai tugas tidak hanya mengajar, tetapi 
ANALISIS KEBIJAKAN PEMBELAJARAN SECARA LURING

DI SMK VETERAN 1 SUKOHARJO

(Narani Agesti, Muhammad Nur Isdaryono, Fauzi Rachman)

juga mendidik, membentuk sikap mental dan kepribadian siswa. Oleh karena itu guru dituntut mempunyai profesionalisme tinggi.

Oemar Hamalik (2002:39) mengatakan bahwa "Guru akan melaksanakan tanggungjawab apabila ia memiliki kompetensi yang diperlukan”. Kompetensi yang dimaksud adalah kompetensi mengajar yang merupakan kemampuan atau kecakapan seseorang yang memiliki pengetahuan, keterampilan dan pengalaman yang dapat diterapkan dengan baik dan penuh tanggungjawab untuk melaksanakan tugas mengajar. Menurut Supardi (2013) pembelajaran efektif adalah kombinasi yang tersusun meliputi manusiawi, material, fasilitas, perlengkapan dan prosedur diarahkan untuk mengubah perilaku siswa kearah yang positif dan lebih baik sesuai dengan potensi dan perbedaan yang dimiliki siswa untuk mencapai tujuan pembelajaran yang telah ditetapkan.

Pada 11 Maret 2020 Organisasi Kesehatan Dunia (WHO) telah me netapkan wabah Covid-19 ini sebagai andemi global. Alasannya, karena virus tersebut telah menyebar semakin luas di seluruh dunia (Liputan6.com, 2020). Pada masa pandemi sekarang sekolah diminta untuk melakukan pencegahan penyebaran Covid-19, WHO merekomendasikan untuk menghentikan sementara kegiatankegiatan yang berpotensi menimbulkan kerumunan massa. Untuk itu pembelajaran konvensional yang mengumpulkan banyak siswa dalam satu ruangan perlu ditinjau ulang pelaksanaannya. Pembelajaran harus dilaksanakan dengan skenario yang mampu meminimalisir kontak fisik antara siswa dengan siswa lain, ataupun antara siswa dengan dosen.

PPL merupakan salah satu mata kuliah di Universitas Veteran Bangun Nusantara Sukoharjo dengan menerjunkan mahasiswa ke lapangan untuk praktek secara langsung di sekolah. Sasaran dalam kegiatan PPL ini adalah warga sekolah, terutama yang terkait dengan proses pembelajaran maupun kegiatan yang mendukung berlangsungnya proses pembelajaran. Sebagai salah satu syarat untuk mendapatkan gelar sarjana di Universitas Veteran Bangun Nusantara Sukoharjo terutama di Fakultas Keguruan dan Pendidikan maka pada tanggal 14 September 2020 dilakukan program Praktik Pengalaman Lapangan, salah satu sekolah yang menjadi tempat mahasiswa menjalankan program tersebut adalah SMK Veteran 1 Sukoharjo. Program ini juga menyesuaikan kebijakan yang ada disekolah tentang 
pelaksanaan mengajar dan efesiensi kegiatan belajar mengajar menggunakan metode luring ataupun daring.

Karena pendidikan sangat penting untuk suatu Negara maka dalam keadaan apapun pendidikan harus selalu diusahakan untuk berjalan dengan baik. Sehingga pemerintah mengeluarkan kebijakan-kebijakan seperti pembelajaran jarak jauh dan kebijakan lain untuk mengupayakan pendidikan di Indonesia terus berjalan.

\section{METODE PENELITIAN}

Metode penelitian kualitatif adalah metode yang dipakai dalam penelitian ini. Penelitian kualitatif adalah penelitian yang bersifat deskriptif dan cenderung menggunakan analisis. Landasan teori dimanfaatkan sebagai dasar agar fokus penelitian sesuai dengan fakta yang ada di lapangan. Jenis pendekatan penelitian yang digunakan yaitu metode deskriptif, yaitu suatu metode dalam meneliti status sekelompok manusia, suatu objek, suatu set kondisi, suatu sistem pemikiran ataupun suatu kelas peristiwa pada masa sekarang. Tujuan dari penelitian deskriptif ini adalah untuk membuat deskripsi, gambaran, atau lukisan secara sistematis, faktual dan akurat mengenai fakta-fakta, sifat-sifat serta hubungan antarfenomena yang diselidiki.

Metode penelitian kualitatif deskriptif adalah penelitian yang dilakukan untuk mengetahui nilai variabel mandiri, baik satu variabel atau lebih (independen) tanpa membuat perbandingan atau menghubungkan dengan variabel lain (Sugiyono, 2003). enis metode deskriptif yang dilakukan yaitu penelitian perpustakaan Penelitian perpustakaan merupakan kegiatan mengamati berbagai literatur yagn berhubungan dengan pokok permasalahan yang diangkat baik itu berupa buku, makalah ataupun tulisan yang sifatnya membantu sehingga dapat dijadikan sebagai pedoman dalam proses penelitian. Menurut Kartini Kartono (1986: 28) dalam buku Pengantar Metodologi Research Sosial mengemukakan bahwa tujuan penelitian perpustakaan adalah untuk mengumpulkan data dan informasi dengan bantuan bermacam-macam material yang ada di perpustakaan, hasilnya dijadikan fungsi dasar dan alat utama bagi praktek penelitian di lapangan. Karena menggunakan penelitian perpustakaan berarti sumber data diambil dari 
ANALISIS KEBIJAKAN PEMBELAJARAN SECARA LURING

DI SMK VETERAN 1 SUKOHARJO

(Narani Agesti, Muhammad Nur Isdaryono, Fauzi Rachman)

berbagai sumber data yang relevan dengan topik yang diangkat yaitu pembelajaran jarak jauh pada masa darurat Covid-19.

Teknik pengumpulan data yang digunakan pada penelitian ini ada observasi dan wawancara. Observasi (pengamatan) adalah pengolahan data primer diperoleh secara langsung dari responden melalui pencatatan keadaan umum secara langusng di tempat usaha itu sendiri sehingga mendapatkan informasi yang jelas. Wawancara merupakan metode selanjutnya yang digunakan untuk mendapatkan data primer secara akurat dengan memberi pertanyaan terstruktur kepada sampel dan dirancang untuk memperoleh informasi (data) dari responden. Jenis wawancara yang digunakan dalam praktikum ini adalah wawancara personal, yaitu antara mahasiswa dengan responden informasi yang relevan

\section{HASIL DAN PEMBAHASAN}

Pendidikan merupakan hal terpenting yang ada dalam kehidupan, hal ini membuktikan bahwa setiap warga negara berhak mendapatkannya. Pendidikan juga bagian dari proses perjalanan kehidupan manusia untuk menjalankan keberlangsungan hidup. Ada 3 jenis- jenis pendidikan yang mampu didapatkan yaitu Pendidikan Informal atau pendidikan yang ada di lingkungan keluarga, Pendidikan Formal yang didapatkan dengan cara menempuh pendidikan dan juga Pendidikan Nonformal yang didapat dari cara manusia itu sendiri bersosialisasi dengan lingkungannya.

Pendikan di Indonesia ada 3 jenjang wajib yang dilalui seperti anjuran dari pemerintah yaitu sekolah 12 tahun, mulai dari pendidikan dasar, menengah pertama dan menegah atas. Salah satu pendidikan mengah atas adalah Sekolah Menengah Kejuruan, pendidikan menengah kejuruan adalah pendidikan pada jenjang pendidikan menengah yang mengutamakan pengembangan kemampuan siswa untuk melaksanakan jenis pekerjaan tertentu. Pendidikan menengah kejuruan mengutamakan penyiapan siswa untuk memasuki lapangan kerja serta mengembangkan sikap profesional. Sesuai dengan bentuknya, sekolah menengah kejuruan menyelenggarakan program-program pendidikan yang disesuaikan dengan jenis-jenis lapangan kerja (PP No 29 Tahun 1990). 
Sejak awal tahun 2020 perubahan drastis di bidang pendidikan mulai mengalami revolusi. Pembelajaran yang tadinya didominasi oleh pembelajaran tatap muka harus beralih dengan pembelajaran dalam jaringan (daring) di semua level pendidikan, termasuk perguruan tinggi. Guna mencegah penularan corona virus 2019 (Covid-19), kebijakan pendidikan banyak yang dilahirkan. Surat edaran yang diterbitkan Mendikbud Nomor 3 Tahun 2020 tentang pencegahan Covid-19 pada Satuan Pendidikan dan Nomor 36926/MPK.A/HK/2020 tentang Pembelajaran daring, para pendidik diharapkan menghadirkan proses pembelajaran menyenangkan bagi siswa. Di level perguruan tinggi juga membuat surat edaran yang isinya sama yaitu menerapkan pembelajaran daring dikampus.

Pandemi Covid-19 masuk ke Indonesia pada bulan maret 2020 yang membuat semua aktifitas terutana di bidang pendidikan diliburkan selama 2 minggu pada masa awal pandemi. Pendidikan mulai dilanjutkan dengan sistem daring atau online yang memakan kuota atau data jaringan yang tidak sedikit dan memberatkan orang tua siswa. Bukan hanya orang tua dan siswa, bahkan tenaga pengajar juga merasa kesulitan dikarenakan harus menggunakan sebuah metode yang jarang dipakai oleh kebanyakan tenaga pengajar yaitu melakukan kegiatan belajar mengajar menggunakan sistem daring atau online. Sistem daring tentu mendapat banyak kritik dan masukan dari berbagai kalangan yang menganggap sistem daring dapat dilakukan jika kesiapan sumber daya manusia yaitu pengajar sendiri dan orang tua yang wajib memantau perkembangan peserta didik Maka perlu diadakannya pembelajaran luring atau tatap muka secara langsung dengan tetap memperhatikan protokol kesehatan yang berlaku dan sesuai dengan arahan kebijakan Menteri Pendidikan.

\section{ANALISIS KEBIJAKAN PEMBELAJARAN DI MASA PANDEMI COVID-19}

Menurut tahapan perumusan kebijakan yang dikemukakan oleh Haddad dan Demsky (1995:24), proses tersebut adalah sebagai berikut.

a. Menganalisis situasi yang terjadi

Pada bidang pendidikan langkah ini harus mempertimbangkan aspek yang meliputi konteks sosial, politik, demografi, kebudayaan, dan permasalahan sosial 
ANALISIS KEBIJAKAN PEMBELAJARAN SECARA LURING

DI SMK VETERAN 1 SUKOHARJO

(Narani Agesti, Muhammad Nur Isdaryono, Fauzi Rachman)

yang berpotensi mempengaruhi pengambilan keputusan hingga proses implementasinya pada sektor pendidikan.

b. Membuat beberapa pilihan kebijakan

Kebijakan baru biasanya dibuat dalam situasi ketika terjadi permasalahan akibat keputusan politis atau reorganisasi. Pembuatan kebijakan dapat dilakukan dengan beberapa model tergantung pada situasinya, namun pada kondisi tertentu model-model tersebut dapat digabungkan.

c. Mengevaluasi pilihan kebijakan

Evaluasi dilakukan terhadap pilihan kebijakan melalui aspek desirability (kemenarikan), affordability ( keterjangkauan), dan feasibility (kelayakan). Desirability mencangkup tiga dimensi yaitu apakah kebijakan tersebut akan mampu menarik dan menguntungkan berbagai kelompok stakeholder, kecocokan dengan ideologi dominan dan target pertumbuhan ekonomi pada rencana pembangunan nasional, serta dampaknya pada perkembangan dan stabilitas ekonomi. Aspek affordability pentingkan pengeluaran pendidikan bersifat lebih rentan terhadap perubahan situasi ekonomi dan politik dibandingkan pengeluaran publik lainnya, sehingga berbagai skenario ekonomi perlu dipertimbangkan. Sedangkan, kelayakan mencakup ketersediaan sumberdaya manusia untuk menerapkan perubahan yang dikandung dalam kebijakan tersebut.

d. Membuat keputusan tentang pendidikan

Pengambilan keputusan hingga menghasilkan suatu kebijakan dilakukan dengan mempertimbangkan banyak pertanyaan, menganalisis seberapa jauh atau radikal perbedaan antara kebijakan baru dengan yang lama, dan apakah kebijakan tersebut bersifat operasional.

e. Merencanakan penerapan kebijakan

Penerapan kebijakan perlu direncanakan dengan baik, karena sebaik apapun antisipasinya penerapan kebijakan selalu membawa kejutan bagi masyarakat dan membentuk respons yang menggambarkan hasil dari kebijakan itu sendiri. salah satu mengantisipasi dampak penerapan kebijakan adalah dengan pilot study. 
f. Menilai dampak penerapan kebijakan

Penilaian dampak kebijakan dilakukan dengan kriteria yang hampir sama dengan tahap evaluasi kebijakan. proses penilaian dilakukan dengan mempertimbangkan apa saja dampak dari penerapan kebijakan tersebut, apakah dampak tersebut sesuai dengan harapan, apakah perubahan dapat dijangkau, dan sebagainya.

g. Menentukan siklus kebijakan selanjutnya

Analisis kebijakan merupakan suatu yang tidak berujung. Idealnya, ketika penerapan kebijakan telah selesai dan hasilnya sudah tampak, tahap penilaian kebijakan akan berlangsung dan mengarahkan pada kemungkinan siklus pembentukan kebijakan yang baru.

Kebijakan- kebijakan perlu dikeluarkan seiring dengan berjalannya waktu, hal ini dilakukan dengan mempertimbangkan juga efektifitas dan efisiensi pembelajaran daring secara terus menerus. Melihat hal itu Kementerian Pendidikan dan Kebudayaan bersama beberapa Kementerian lain merancang sebuah kebijakan yang mengatur bagaimana pola kegiatan belajar mengajar dimasa pandemi covid-19. Dengan pertimbangan seperti ancaman putus sekolah, penurunan capaian belajar dan kekerasan pada anak dan risiko eksternal dapat merusak sumber daya manusia yang ada di indonesia. Prinsip kebijakan pendidikan di masa pandemi covid- 19 ini berdasarkan pada 2 aspek yaitu kesehatan dan keselematan peserta didik, tenaga kependidikan, keluarga, dan masyarakat merupakan prioritas utama dalam menetapkan kebijakan pembelaijaran sersta aspek tumbuh kembang peserta didik dan juga kondisi psikososial juga menjadi pertimbangan dalam merancang kebijakan pendidikan di masa pandemi covid- 19 .

Secara legal formal, berdasarkan Peraturan Menteri Pendidikan dan Kebudayaan Nomer 109/2013 Pasal 2, menyebutkan bahwa tujuan PJJ adalah untuk memberikan layanan pendidikan tinggi kepada kelompok masyarakat yang tidak dapat mengikuti pendidikan secara tatap muka, dan memperluas akses serta mempermudah layanan pendidikan tinggi dalam pembelajaran. Dengan begitu dapat diartikan bahwa PJJ adalah suatu sistem pendidikan yang memiliki 
ANALISIS KEBIJAKAN PEMBELAJARAN SECARA LURING

DI SMK VETERAN 1 SUKOHARJO

(Narani Agesti, Muhammad Nur Isdaryono, Fauzi Rachman)

karakteristik terbuka, belajar mandiri, dan belajar tuntas dengan memanfaatkan Teknologi, Informasi.

Pada bulan Agustus 2020, pemerintah melalui Kementerian Pendidikan dan Kebudayaan mengeluarkan kebijakan baru diantara kurikulum darurat dan perluasan pembelajaran tatap muka untuk zona kuning dan hijau. Kurikulum darurat dibuat agar mampu menyederhanakan kompetensi dasar yang mengacu pada kurikulum 2013 dan juga kurikulum ini digunakan dalam kondisi khusus seperti penyerhanaan kompetensi dasar untuk setiap mata pelajaran sehingga berfokus pada kompetensi esensial dan kompeteni prasyarat untuk kelanjutan pembelajaran di tingkat selanjutnya. Harapannya kurikulum darurat ini mampu memudahkan proses pembelajaran di masa pandemi dan dapat juga mmbantu mengurangi kendala yang dihadapi guru, orang tua, dan anak selama masa pandemi. Kebijakan perluasan pembelajaran tatap muka untuk zona kuning dan hijau yang dicanangkan oleh pemerintah tentu memiliki beberapa pertimbangan seperti penerapan protokol kesehatan ketat seperti jarak minimal, maksimal peserta didik dalam kelas, jadwal pembelajaran, dan tetap mematuhi pola hidup bersih sehat dan sebagai catatan pembelajaran tatap muka di sekolah di zona kuning dan hijau memang diperbolehkan namun tidak diwajibkan.

\section{IMPLEMENTASI KEBIJAKAN PENDIDIKAN SELAMA PANDEMI COVID- 19}

Di era pandemi COVID-19 ini tentunya tidak memungkinkan untuk menerapkan pembelajaran dilaksanakan secara face to face atau secara langsung mungkin setidaknya bisa dilakukan dengan jarak jauh atau virtual yaitu pembelajaran secara online dengan melakukan live e-learning melalui berbagai platform aplikasi yang tersedia seperti Zoom, Google Meet, Google Classroom yang merupakan media berbasis aplikasi yang dapat dioptimalkan untuk wadah pembelajaran.

Melalui media aplikasi elektronik tersebut tenaga pendidik juga dapat mentransfer pengetahuan dan keterampilan seperti biasanya saat melakukan pembelajaran secara face to face atau langsung. Dalam pembelajaran jarak jauh atau online ini juga tetap bisa membangun karakter peserta didik misalnya saja 
dapat dilihat dengan disiplin waktu dalam memulai dan mengakhiri pertemuan kelas daring atau online, disiplin waktu batas waktu upload tugas, kemandirian melalui tugas individu, kerjasama melalui tugas kelompok dan etika dalam berbicara atau menulis saat live elearning berlangsung antara peserta didik dengan tenaga pendidik.

Keluarnya kebijakan pendidikan selama masa pandemi ini perlu didukung oleh berbagai pihak terkait dan melalui pertimbangan yang cukup matang. Sebab kebijakan seperti perluasan pembelajaran tatap muka untuk zona kuning dan hijau harus mengajukan ijin ke pihak terkait dan protokol kese hatan ketat. Salah satu cara yang dilakukan SMK Veteran 1 Sukoharjo dalam mengimplementasikan kebijakan ini dengan cara pembuatan satgas covid-19 yang terus berjaga untuk menjaga protokol kesehatan bagi setiap orang yang hendak memasuki area sekolah. Satgas covid ini terdiri dari mahasiswa peserta PPL dan beberapa guru yang bertugas bergantian setiap harinya. Kelengkapan dalam penegakkan protokol kesehatan ini diantaranya adalah termogun, hand sanitizer, tempat mencuci tangan yang tersebar di 3 titik, masker n95.

Para tenaga pendidik dan peserta didik juga tentunya dengan diterapkannya protokol kesehatan tentu akan merasa sedikit tenang dan aman saat proses belajar mengajar dilaksanakan. Wali murid atau orang tua murid di rumah juga akan setuju apabila pembelajaran sudah dilakukan secara tatao muka langsung dengan adanya penerapan protokol kesehatan dan juga orang tua atau wali murid tentunya tak terlalu khawatir ketika anaknya melakukan proses belajar mengajar di kelas seperti sekolah pada biasanya.

Pada praktik pengalaman lapangan yang dilakukan di SMK Veteran 1 Sukoharjo yang dilaksanakan mulai tangal 14 September 2020 sampai dengan 16 November 2020 masih menggunakan metode daring sebagai sistem pembelajaran dan pada implementasinya masih sangat kurang sebab masih ada peserta didik yang belum maksimal dalam mengikuti kegiatan belajar mengajar yang diadakan oleh peserta PPL. Adapun kendala- kendala yang dihadapi peserta didik selama mengikuti kegiatan belajar mengajar dari peserta PPL yaitu jaringan data dan kemampuan penyerapan materi yang diberikan. Maka dari itu dibuat sebuah 
ANALISIS KEBIJAKAN PEMBELAJARAN SECARA LURING

DI SMK VETERAN 1 SUKOHARJO

(Narani Agesti, Muhammad Nur Isdaryono, Fauzi Rachman)

inovasi baru dengan pemberian materi vidio kreatif dengan harapan peserta didik mampu memahami materi dengan baik dan dapat dipelajari setiap saat.

\section{PENERAPAN PEMBELAJARAN LURING}

Kata luring merupakan sebuah akronim dalam kamus besar bahasa indonesia berarti luar jaringan biasa disebut offline atau tatap muka. Luar jaringan yang dimaksud di sini merupakan jaringan internet, salah satu contoh luar jaringan yaitu pembelajaran lewat siaran televisi seperti TVRI ataupun radio sebagai media pembelajaran luring. Namun luring juga secara artian lain dapat diartikan pembelajaran secara tatap muka langsung.

Pembelajaran luring tetap dilaksanakan sebagai bentuk ujian dan sebagai bekal menjadi tenaga pendidik kepada mahasiswa peserta PPL dan luring juga dilaksanakan hanya di kelas XII sebagai ujian praktikum. Pembelajaran luring di kelas XII dilaksanakan dengan mengikuti instruksi kebijakan pendidikan selama pandemi covid-19 dengan memaksimalkan kuota peserta didik dalam satu ruangan kelas sebesar 50\% dari total peserta didik yang dapat ditampung di suatu kelas. Agar seluruh peserta didik mendapatkan hak dalam pembelajaran luring dan agar semua peserta didik dapat menjalankan ujian praktikum, maka kebijakan 2 kloter diterapkan. Kloter pertama dimulai pukul 08.00 WIB sampai puk1 09.00 WIB dan pemberian jeda selama 1 jam untuk strelisisasi ruangan. Untuk kloter yang kedua dimulai pada pukul 10.00 WIB dan selesai pada pukul 11.00 WIB.

Untuk mahasiswa peserta PPL yang melakukan kegiatan belajar mengajar secara luring masih belum bisa dilaksanakan secara terus menerus sebab wilayah Sukoharjo masih termasuk zona merah covid-19 yang menyebabkan implementasi pembelajaran luring masih terhambat dan belum terlaksana secara maksimal walaupun sudah melakukan persiapan- persiapan matang seperti yang diarahan pemerintah dalam kebijakan pendidikan. Meski demikian bukan berarti kegiatan belajar mengajar secara luring tidak dapat dilaksanakan, pada tanggal 5 November 2020 pihak sekolah mencoba untuk melakukan pembelajaran secara luring dengan peserta didik $50 \%$ dari total maksimal muatan kelas yang dipakai.

Pembelajaran secara luring juga dilaksanakan dengan pelaksanaan protokol kesehatan yang ketat dan sesuai standar kesehatan yang berlaku. 
Sebelum masuk kedalam kelas untuk memulai pembelajaran, para peserta didik dan tenaga pendidik yang memasuki ruangan akan dicek suhu tubuh dengan menggunakan termogun, dan diberikan handsanitizer. Didalam ruangan kelas sudah diberi tanda untuk tempat duduk mana saja yang boleh di tempati dan yang tidak boleh dengan pemberian jarak minimal 1,5 meter antar peserta didik. Pembelajaran sendiri diberikan waktu selama 30 menit, 20 menit untuk pemberian materi dan 10 menit untuk sesi tanya jawab.

\section{EFEKTIFITAS DAN EFISIENSI PEMBELAJARAN SECARA LURING}

Dunia pendidikan saat ini tengah mendapatkan pembelajaran yang cukup berharga, proses belajar mengajar yang biasa di sebuah gedung dan terpusat dinamakan sekolah. Akibat adanya pandemi covid- 19 ini pada akhirnya membuat proses belajar mengajar diubah menjadi pembelajaran jarak jauh dari rumah. Pada praktiknya pembelajaran jarak jauh ini juga memberikan efek kesadaran setidaknya kepada para orang tua yang kembali menjadi pendidik sebenarnya pada anak-anak, karena sebelumnya kebanyakan dari para orang tua hanya disibukan dengan urusan pekerjaan dan memberikan wewenang kepada sekolah seutuhnya sebagai pendidik bagi anak- anak mereka.

Banyaknya keluhan dari para orang tua tentang beratnya menjadi pendidik dikala sang anak mendapatkan tugas dan mendapat pertanyaan seputar pelajaran membuat para orang tua meminta kepada pemerintah untuk mengadakan pembelajaran secara tatap muka. Pembelajaran luring memang sudah dapat dilaksanakan secara bertahap di beberapa sekolah di zona kuning dan hijau, akan tetapi pembelajaran luring ini perlu diadakan terus dengan protokol kesehatan yang ketat. Pembelajaran luring sendiri ternyata sangat efektif dan untuk penyampaian materi meski dalam kondisi pandemi seperti sekarang ini yang memaksa peserta didik dan tenaga pengajar harus lebih meluangkan waktu didepan gadget dalam kurun waktu yang cukup lama. Untuk menyeimbangkan aspek pemahaman materi, kondisi kesehatan jasmani dan rohani maka pembelajaran secara luring tetap dilaksanakan meski tidak sesering pembelajaran seperti biasa dikala tidak adanya pandemi. Hal ini dilakukan dengan perhatian 
ANALISIS KEBIJAKAN PEMBELAJARAN SECARA LURING

DI SMK VETERAN 1 SUKOHARJO

(Narani Agesti, Muhammad Nur Isdaryono, Fauzi Rachman)

khusus seperti penegakkan protokol kesehatan, pola hidup bersih sehat dan tetap memakai masker ketika dalam kerumunan seperti di kelas.

Kebijakan pembelajaran luring dimasa pandemi ini perlu diadakannya evaluasi bersama dengan pihak terkait, sebab pola pembelajaran luring ini perlu dilakukan setidaknya 1 pertemuan di setiap minggu agar kondisi peserta didik dapat dipantau dan penyerapan materi yang diberikan bisa terlihat apakah peserta didik mampu menyerap materi- materi yang disampaikan atau tidak. Pembelajaran secara luring ini sangat dibutuhkan sebab semakin hari semakin tidak terkontrolnya peserta didik dalam mengikuti proses pembelajaran. Hal ini dibuktikan dari cara menjawab soal dan tugas yang diberikan mahasiswa peserta ppl kepada peserta didik. Cara menjawab yang bahkan diluar pembahasan dan tergolong singkat dan tidak menjelaskan apapun. Hal ini membuktikan bahwa peserta didik sudah mencapai titik kejenuhan dalam mengikuti pembelajaran.

Pada praktik mengajar yang dilakukan mahasiswa peserta PPL pada tanggal 5 November 2020, dapat dilihat dari antusias peserta didik yang semangat mengikuti pembelajaran dengan materi sejarah yaitu imperialisme dan kolonialisme bangsa barat di indonesia. Mulai dari antusias untuk mendengarkan materi, sampai dengan antusias untuk berebut memberikan pertanyaan atas materi yang disampaikan. Namun sangat disayangkan praktik mengajar atau proses pembelajaran secara luring hanya berlangsung selama 30 menit dan dirasa kurang efektif karena masih banyaknya penjelasan materi yang belum disampaikan.

\section{KESIMPULAN DAN SARAN}

Sistem pembelajaran secara daring memang sangat efektif untuk kondisi pandemi seperti sekarang ini. Namun hal yang harus digaris bawahi ialah proses pembelajaran ini yang sudah berjalan selama 6 bulan atau dapat dikatakan sudah berjalan 1 semeseter penuh. Perlunya pembelajaran secara luring tidak hanya untuk mengatasi kejenuhan dan kurangnya peserta didik menyerap materi yang disampaikan, namun juga sebagai antisipasi dampak negatif yang diterima oleh anak di antaranya ancaman putus sekolah, penurunan capaian belajar dan kekerasan pada anak dan risiko eksternal dapat merusak sumber daya manusia yang ada di indonesia. Oleh karena itu gagasan pemerintah melalui Kementerian 
Pendidikan dan Kebudayaan yang menyatakan perluasan pembelajaran pada zona kuning dan hijau perlu dikaji ulang.

Pola pembelajaran secara luring sebenarnya dapat dilaksanakan dengan baik seperti yang diterapkan di SMK Veteran 1 Sukoharjo dengan tetap memperhatikan protokol kesehatan dan menggunakan 50\% kuota maksimal kelas untuk satu ruangan. Ditambah lagi dengan pemberian handsanitizer dan sterilisasi ruangan diharapkan juga pembelajaran secara luring ini terus dilakukan hingga negara Indonesia terlepas dari pandemi covid- 19.

\section{DAFTAR PUSTAKA}

Hamalik, Oemar. 2004. Pendidikan Guru Berdasarkan Pendekatan Kompetensi. Jakarta : Bumi Aksara.

Sugiyono. 2012. Metode Penelitian Kuantitatif Kualitatif dan R\&D. Bandung: Alfabeta.

Supardi. Sekolah Efektif, Konsep Dasar dan Praktiknya. Jakarta: Rajawali Pers, 2013.

Suyahman, 'Analisis Kebijakan Pendidikan Gratis di Sekolah Menengah', Jurnal Pendidikan Kewarganegaraan, 6 (2016), 1047-54.

Syaharuddin, S., Rahman, A. M., \& Fitriyani, R. (2020). Utilization Of Social Community as Learning Resources On Social Studies. The Kalimantan Social Studies Journal, 1 (1), 18-24.

Taufik, Ali, 'Perspektif Tentang Perkembangan Sistem Pembelajaran Jarak Jauh Di Kabupaten Kutai Kartanegara Kalimantan Timur', Jurnal Pendidikan \& Konseptual, 3.2 (2019), 88-98. 